\title{
PACATAL IN ANAESTHESIA:
}

\section{A PRELIMINARY REPORT* *}

\author{
John I. DAVIES, M D, F R C P.(C), F.F.A R C S \\ Donalda H. M. HugGins, M.D. \\ Christopher F WOLKENSTEIN, M.D **
}

THE INTRODUCTION of the lytic cocktail into clinical use by Labont and Huguenard in 1951 (1), and the excellent results claimed, stmmulated interest in so-called "ganglio-plegic" drugs and "l'hibernation artificielle" Whatever one's opinion may be regarding the usefulness and rationale of such techniques, it must be agreed that new, powerful, and interesting drugs have been added to the anaesthetist's armamentarium One of these, chlcrpromazine has been the cause of lively controversy, mainly because some investigators seized on the unusual properties of the drug to sustain hypotheses of their own making (2) That at least 2,000 papers have been published on chlorpromazine proves the widespread interest in this drug In Canada, these include valuable papers by many investigators

The concept of tranquillizing action, apart from any eftects of hypnosis or analgesia, has efnerged Recently the term "Ataraxı" meaning "calmness, untroubled by mental or emotional excitement" has been used by Fabing $(3,4)$ Many wellestablished drugs such as the narcotics and barbiturates may produce this effect in addition to their other well-known properties

Because of the stress and strain of present-diay living, drugs having a predominately tranquillizing effect have extensive chnical application. The narcotics, barbiturates, and hypnotics because of undesi able effects have limited therapeutic usefulness when only a tranquulluzing effect is desired. Drugs such as Serpasil $(5,6)$, Miltown or Equanıl (Meprobamate) $(7,8)$ and more recently Suavitl (Benactyzine HCC) $(9,10)$, in spite of some disadvantages, have been found very useful clinically in producing relief of nervous tension. As a result of these successes, drugs of a similar nature can be expected to flood the market Because the tranquillizing properties of these drugs may be used to advantage by our specialty, anaesthetists should maintain an interest in the investigation of such drugs in the hope that eventually an ideal one may be found.

The phenothiazine derivatives deserve special consideration as members such as chlorpromazine, promethazine, Diparcol, and Avomine have already found a place in medicine

In a search for less toxic phenothiazine derivatives, Schuler and Nezel synthesized eight compounds each having a terminal piperidine ring attached to the nitrogen atom of phenothiazıne. These compounds were investigated by

A phenothiazıne derivative

- opresented at the meeting of the Western Divi'sons Canadian Ancesthetists' Society, Vancouver, B C, April 5-7, 1956

* From the Departments of Anaesthesid, University of Manitoba, Winnipeg General Hospital, and the Childrens' Hospital, Winnipeg 
Nieschulz in 1954 and the most promising one, P 391 or Pacatal, was subjected to an exhaustive and detailed study (11)

Pacatal is N-methylpiperidyl-3-methylphenothrazine and its structural formula is shown in Figure 1

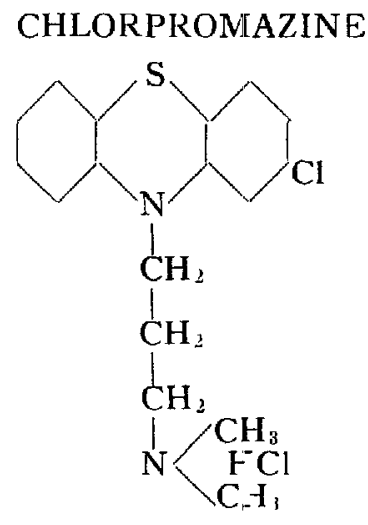

DIPARCOL<smiles>CCN(CC)CCCCCCCSC1CCCCC1N(CC)CC</smiles>

\section{PROMETHAZINE}<smiles></smiles>

PACATAL<smiles>CN1CCCC(CN(CCCCCCSC2CCCCC2)C2CCCN(C)C2)C1</smiles>

Figune 1 Structural formulae of some phenothiazine derivatives

\section{Pharmacology}

Pacatal hạs been extensively investigated in various laboratory anımals by many workers including Nieschulz (12), Gadermann (13), Donat (14), and Horatz (15) and their findings are briefly summanzed.

Pacatal was absorbed and eliminated quickly

$\mathrm{LD}_{50}$ varied from $20 \mathrm{mg} / \mathrm{kg}$ i v. in rabbits to $750 \mathrm{mg} / \mathrm{kg}$ s c in mice. Dally administration of up to $20 \mathrm{mg}$. $/ \mathrm{kg}$. orally to dogs for six inonths produced no untoward effects.

Circulatory effects included decreased capillary permeabilsty, vasodilatation. and vasodepression. In anaesthetized dogs, doses of $5 \mathrm{mg} / \mathrm{kg}$ produced moderate depression of blood pressure $(20 \mathrm{mg} . \mathrm{Hg})$ which could be reyersed by vasopressol agents, but was accentuated by Pendiomid or Arfonad The main effects on the heart were "intravascular anaesthesia," protection against epmephrineinduced and hypothermic arrhythmias, and coronary vessel dilatation in the isolated guinea-pig heart. 
Pacatal seemed to depress the sympathetic nervous system producing partial adrenergic blockade and some measure of adrenolytic actuvity, in that the pressor, but not the local vasoconstrictor or hyperglycaemic effects of adrenalin was inhibited Blood sugar levels were not usually affected Nor-epinephrine was not blocked. The carotid sinus reflex was inhıbited

Parasympathetic activity was apparently depressed as salıvary secretions were lessened, gut activity was reduced, vasodepression from vagal stımulation was inhibited, gastric secretions were reduced, and the incidence of experimentally produced gastric ulcers was lessened. The effects of acetyl choline were unchanged. Mydriatic action was slight.

Action on the central nervous system was a predommantly quietng effect and marked sedation was seen only following higher doses. Pacatal was a mild anticonvulsant The hypnotic activity of barbiturates was prolonged without a decrease in the rate of fall of the plasma concentration of the barbiturates. The anaesthetic action of ether was markedly increased Pacatal is a mild analgesic and the analgesic properties of morphine, Demerol, and phenacetm were potentrated. Pacatal was an effective local andesthetic agent The action of succinylcholine was potentrated

Pacatal in large doses (50 mg./kg. in rabbits) loweied normal body temperature only slightly, but had strong intipyrexial properties The basal metabolic rate was reduced up to 23 per cent

Pacatal administration was not followed by albuminuria but haematuria was produced by large doses (as by chlorpromazine). Liver damage was not reported. Pacatal is a mild anti-histamine

The pharmacological activities of Pacatal are summarized and compared with some phenothrazine derivatıves in Table I

I.IBLE I

Summary of Pharmacological Activity of Some Phlenothiazine Derivativis (after Horatz, 17)

\begin{tabular}{|c|c|c|c|c|}
\hline & Phenergan & Diparcol & Largactıl & Pacatal \\
\hline Antihistamine & +++ & + & + & $+t$ \\
\hline Parasympathetico-lytic & ++ & + & + & ++ \\
\hline Sympathetico-lytic & + & +++ & +++ & ++ \\
\hline Blood pressure lowerng & + & + & $+t$ & ++ \\
\hline Blood pressure stabilizing & $+t$ & + & ++ & ++ \\
\hline Analgesic & + & + & ++ & $+t$ \\
\hline Metabolısm lowering & + & $+t$ & ++ & ++ \\
\hline Temperature lowering & + & $+t$ & +++ & + \\
\hline Local anaesthetic & +++ & + & $+t+$ & $++t$ \\
\hline Anticonvulsant & ++ & $+t+$ & $+t+$ & + \\
\hline Strong action +++ & Meduum ac & ++ & Weak action & \\
\hline
\end{tabular}

\section{Clinical Studies by Other Investigators}

It must be remembered that accurate inferences cannot always be made from the results of experıments with anımals (16). Apart from species differences, 
much higher doses may be given to anımals with apparently different iesults. Also animals may be under barbiturate anaesthesı to facilitate some recording, such as blood pressure changes.

Horatz first reported the clinical use of Pacatal in 439 cases (17) and later in 1,144 patients undergoing surgery (18). Premedication was with repeated $50 \mathrm{mg}$. doses of Pacatal, morphine being withheld except in the case of severe pain. The total dose and route of administration depended on the severity of the procedure but his dose schedule included barbiturates, Dolantin and in children atropine This series included 403 pulmonary, 21 cranial, and 20 cardiac operatons. Minor cases were "pretreated" and in major cases Pacatal was used for "potentiation of narcosis." Horatz later enlarged his series to over 5,000 cases (19) He combined Pacatal with Pendiomid for controlled hypotension, and with refrigeration in place of the "lytic cocktail," cldiming that using a single drug is advantageous. He used Pacatal for many hours preoperatively Good results were claimed but hypersecretion after thoracic surgery, hyperpyrexia (easily controlled by amidopyrine), and increased difficulty in judging the patient's postoperative condition were occasional disadvantages Toxic potentiation of narcotics'was noted

\section{OTHER RJPORTED Uses}

Pacatal has been used successfully in combination with barbiturates in "Schlaftherapie" or therapeutic sleep (20)

In psychiatry encouraging results were obtained with 50 patients suffering from mild anxiety states (21) but hypochondriacal schizophrenics were not affected (22). Manics showed a wide variation in response and best results were claimed in anxiety states and drug addiction (23)

Lindsay (24) has used Pacatal in more than 50 psychiatric patients in office practice and noted its good sedative action The treatment was later modified because of occasional complaints of "blurred vision," found to be caused by difficulty in accommodation.

Good results have been reported by Kline (25), but complications including hyperpyrexia; dryness of the mouth, urinary retention, and lack of therapeutic benefit were reported.

Pacatal has been used to potentrate the analgesic action of morphine in cases of inoperable carcinoma (26).

The drug has aroused wide interest mainly in Germany At least thirty papers have been published and more can be expected in the near future

\section{ClinjCal Study}

Pacatal is at present available as tablets containing $50 \mathrm{mg}$. or $25 \mathrm{mg}$. of Pacatal base (as Hydrochloride), and as ampules ( $2 \mathrm{cc}$ ) containing $25 \mathrm{mg}$ Pacatal base (as Acetate) per cc The $\mathrm{pH}$ of the solution is 56 to 58 at $25^{\circ} \mathrm{C}$ The solution is not physically compatible with solutions of Pentothal, Demerol, chlorpromazine, promethazine, muscle relaxants, or with normal saline, but can be diluted with distilled witer or 5 per cent Dextrose wateı. 


\section{Local EfFects}

Pacatal, like most phenothiazine compounds, is irritatıng to tissues. Early in the series, Pacatal was given intravenously undiluted to 35 patients and a transient phlebo-thrombosis occurred in two patients Since we began diluting Pacatal solution with at least three times its volume, no phlebo-thrombosis has resulted from its use. Following intramuscular injection in 106 patients, 84 com s]ained of sore buttocks after operation This was particularly noticeable in chilc ren when relatively large doses had been given Because of this, oral administration is preferred for premedication, particularly since this route gives equally sutisfactory results. Oral administration produced no nausea, vomiting or gastric discomfort

\section{Dosage}

Early in the series, Pacatal was given intravenously to adult patients in doses ranging from 25 to $250 \mathrm{mg}$. It was found that the small doses prodiced no obvious effects, and that the large doses used produced no more of the desirable effects than moderate doses

The usual dosage evolved for adults was 100 to $200 \mathrm{mng}$ (about $1 \mathrm{mg}$ per pound of body weight) and relatively larger doses for children (about 1/2 $\mathrm{mg}$ per pound of body weight) by whatever loute was chosen

In our present series, Pacatal was given to 352 patients ranging! in age from 2 to 86 years There were 204 children and many of the adults were "poor risk" patients. The drug was used in the following ways:

\section{Present Investigation}

1. H.S. Sedation-56 cases

2. Premedication either alone or in various combinations with Atropine and Demerol-204 cases

3. Following usual premedication, in conjunction with anaesthesia, exther immediately preceding induction or during the course of anaesthesia-148 cases.

4. Postoperatively -42 cases

\section{Results}

Of the 56 patients who had recelved Pacatal orally at bedtıme, 47 slept well

Patients who had recenved the usual dose of Pacatal about 1 to $1 \frac{1 \% 2}{2}$ hours previously usually arrived in the operating room in a tranquil frame of mind A few were asleep when left undisturbed. but awoke readily. Most rested peacefully and though alert mentally, they appeared to be unusually calm in the acceptance of their surroundings This was particularly noticeable in the case of children who would tolerate venipuncture for Pentothal administration with unusual equanimity.

Sedation was considered excellent in 26 , good in 142 , and poor in 37

In most cases salivary secretions were greatly reduced, particularly in adults, and although the mouth was not completely dry, excessive secretions were not troublesome during subsequent anaesthesia Secretions, when present, were of 
normal consistency and not tenacious. In children, particularly during ether anaesthesia, secretions were sometimes troublesome. Consequently in addition to Pacatal, atropine was given in half the usual dosage and this combination was satisfactory in most cases.

In 53 cases, Demerol (in dosage $y_{2}^{\prime} y_{1}^{\prime} \mathrm{mg}$ per pound) wạs given as well as Pacatal Sedation was better than would be expected from the use of etther drug alone, but no potentiation of the toxic effects of Demerol was seen, suggesting that the increased sedative effect was one of "combination" rather than potentiation. No respiratory or cardiovascular depression was seen, even in elderly subjects

Whenever the drug was given immediately before operation, alone or after the usual premedication with atropine and Demerol or morphine, the patients within three minutes become more sedated without increased respiratory depression Even intravenous doses up to $250 \mathrm{mgm}$ given rapidly produced little effect on blood pressure or pulse rate

No peripheral anti-sympathetic effects were seen. The size of the pupil was not affected, there was no congestion of nasal mucous membrane; no venous dilatation, no warm dry flushed skm and sweating, if present when Pacatal was given, was not abolished

No amnesic effects were attributed to the drug Hyperexcitability did not occur.

\section{EFFECts duRing Anaesthesia}

\section{Central Nerwous System Effects}

The induction dose of Pentothal to the loss of the lid reflex was usually reduced by about 20 to 30 per cent of anticipated dose, and this estimated reduction of Pentothal dosage was confirmed in 9 patients who had received Pentothal for induction a short time pieviously

All inhalation anaesthetic agents' commonly used were slightly potentiated in that the course of anaesthesia was unusually smooth and patients could be maintained in light anaesthesia with minımal amounts of agents So-called "automatic" anaesthesia was usual it reflex activity returned during too light a level of mantenance; the patients' reactions were slight, and not a vigorous protest. Return to an adequate level of anaesthesia was easily accomplished. This was particularly noticeable during tonsil dissections There was no increased respiratory depression and it was felt (as in the case of neteotics) that Pacatal increased the duration of action of agents rather than therr depression of vital functions. When Pacatal was given during anaesthesia, similar results were noticed and the level of anaesthesia apparently deepened The acton of muscle relaxants did not appear to be affected.

\section{Cardiovascular Effects}

During anaesthesia changes in blood pressure or pulse rate were seldom seen and could usually be attributed to definite operative or anaesthetic causes. However, the hypotensive effect of Pentothal was sometımes exaggerated particularly 
in elderly hypertensive subjects. In 9 such cases, a normal response to small doses of Methedrine was obtamed. Protection agamst untoward reflex activity was hard to evaluate as Pacatal was not used to cover errors in anaesthetic technuque and any excessive blood loss was replaced

\section{Postoperative Period}

Increased postoperative depression and delay in regaining consciousness was not seen except when patients had been given usual (but, following Pacatal. relatively large) amounts of Pentothal or ether. This depression was not seen when further experience with the drug showed that only minimal amounts of anaesthetic agents were necessary to maintain adequate depth of anaesthesia

Though conscious in response to questioning or painful stımuli, most patients usually slept peacefully if left undisturbed. This tranquil state lasted for about $4 \frac{1}{2}$ to 5 hours after administration and narcotics were rarely needed When this tranquil state wore off, most patients rested quetly for about another six hours. particularly if usual doses of analgesics had been given to combat pain

Postoperatıve restlessness was unusual, particularly in children following minor operative procedures

The incidence of immediate postoperative emesis appeared to be greatly reduced, it occurred in 105 per cent of cases. Ten patients with a history of postanaesthetic hyperemesis were given Pacatal during anaesthesia and three did not vomit after operation

No profound hypotension was seen, but a slight hypotension of 10-15 per cent of expected blood pressure levels was sometimes seen, when moderate amounts of Pentothal or ether had been given during anaesthesia

In the postoperative period, Pacatal was repeated 27 times when its main effect had apparently worn off Emesis was controlled in 16 out of 18 patients and restlessness was improved in 6 out of 9 cases

There was no increased incidence of urmary retention after operation and no case of albuminuria or haematuria attributable to the use of Pacatal Increased secretions of the respiratory tract or hyperpyrexia were not seen There was no clinical evidence of liver damage or alteration in the blood picture.

\section{OTHER USES}

\section{In Obstetrics}

Pacatal was given in doses of $150 \mathrm{mg}$ intravenously to 15 multigravida during the second stage of labour No analgesic effects were seen and no potentiation of Demerol which had been given to 12 patients Course of labour was very rapid (possibly even accelerated) and all delivered normally. No effects on the babies were seen. The patients were tranquul after delivery

Pacatal $100 \mathrm{mg}$ was given intravenously before spinal anaesthesı to five patients. Hypotension in 3 cases responded rapidly to Methedrine. A fair sedative effect was obtained in all cases, but this seemed to be abolshed when Methedrine was given

Pacatal was given $50 \mathrm{mg}$ orally t.id to 12 patients suffering from emesis gravidarum. Seven were cured, 3 helped and 2 not affected 


\section{Status Epilepticus}

Pacatal (100-200 mg. 1M) was given to two patients in Status Epilepticus, having very frequent seizures uncontrolled by large doses of Dolantin, paraldehyde, and barbiturates In both cases the number and severity of the attacks were greatly reduced but only a slight increase in somnolence occurred

\section{Shock}

Although Pacatal is not a powerful vasodilator or anti-adrenergic agent. the work of Martin (26) prompted our use of Pacatal in one case of protound shock caused by severe head injury. The role of Pacatal combined with hypothermia was difficult to evaluate but the patient made a good immediate recovery.

\section{E.E.G. and E K.G Investigation}

Pacatal was given intravenously to a healthy $176 \mathrm{lb}(75 \mathrm{Kg})$ adult male and the E E.G and E.K G findings were as follows

The restıng E.E G. showed normal alpha actıvity at $11 \mathrm{c} / \mathrm{s}$

Drug A (Pacatal $100 \mathrm{mg}$.) showed no noteworthy effect

Approximately three minutes after the administration of Drug B (a second dose of Pacatal $100 \mathrm{mg}$ ) the alpha activity was replaced by slow activity at $5 \mathrm{c} / \mathrm{s}$ and $7 \mathrm{c} / \mathrm{s}$

The pattern was not that usually associated with drowsiness or sleep, it does not resemble the effects of barbiturates and is worthy of further investigation

The E K G. tracings showed no abnormalities.

\section{Discussion}

The precepts stated by Melville (27) and by Gilbert and co-authors (28) provided valuable guidance in attempting to evaluate Pacatal

Our observations on the effects of Pacatal have been varied and difficult to assess The main reason for this was that. compared with the usual definite effects of chlorpromazine, those of Pacatal were less obvious-almost subtle or unobtrusive At first, we consıdered that Pacatal produced very little effect, but as the series enlarged we became more convinced of the usefulness of Pacatal.

In this clnical study it was mevitable that comparison would be made with the effects of chlorpromazine Although the actions of both drugs are similar in many respects, Pacatal appears to have a potency roughly $1 / 10$ to $1 / 15$ that of chlorpromazine. Pacatal has a much milder action and more even effect

In comparative doses Pacatal produces less drowsiness and detacliment from surroundings, but at least equal tranquillizing effects Fewer side effects were seen with Pacatal as hypotension was unusual and never profound. The peripheral sympatheticolytic effects of chlorpromazine were never seen. Pallor has been observed in ambulatory patients and in anaesthetized patients when blood loss was excessive. In such cases absence of hypotension and tachycardiat suggested that the peripheral vasoconstriction was adequate in mantaining normal cardiac output. If the carotid sinus reflex was depressed it was not apparently abolished 
It is impossible without determinations of blood levels to determine whether in fact potentiation of narcotics and anaesthetic agents does occur, or whether the augmented effects were caused by "combinations." This drug lacks specific action as no one pharmacological effect is outstanding. Although the action of Pacatal appears to be mainly central, it would be invaluable if further pharmacological studies could determine its site of action.

In the postoperative period, decreased restlessness, nausea, and vomiting were a definite advantage. Compared with chlorpromazine, postoperative depression was seen less regularly and when present was of less profound and shorter duration. The further 5 or 6 hours of restfulness were of benefit to patients.

Pacatal may have specific usefulness in "poor rısk" patients, as its use may fulfil the concept of almost homeopathic doses in the admuristration of other agents (29), with minimal side effects.

It is possible that further investigation will confirm its pharmacological value in preventing arrhythmias durng hypothermia and intracardiac operations.

In view of the low toxicity of Pacatal and its many desirable features we feel that this agent merits further and more extensive investigation to determine its place of usefulness in anaesthesia and related fields

\section{SUMMARY}

The history of the introduction of a new phenothiazine derivative into medicine has been reviewed and allusion made to the concept of ataraxic drugs.

The pharmacology of Pacatal in animals has been briefly reviewed and also the clinical findings of other investigators.

This report deals with observations made on the use of Pacatal for 352 patients undergoing surgery, 44 obstetrical patients, and other uses in 3 patients.

Doses of $100-200 \mathrm{mg}$ ( $1 \mathrm{mg} . / \mathrm{lb}$ ) were found effective irrespective of the route administered

Favourable effects noted include. good preoperative sedation, tranquillization more noticeable than hypnosis, ease of control of anaesthetic procedure (between anaesthesia and analgesia), possibility of decreased amounts of anaesthetic agents, antisecretory effects enabling the use of atropine to be avolded in adults, normal response to vasopressors, tranquil postoperative course, decreased incidence of postoperative nausea and vomiting

The drug was relatively non-toxic to the cardiovascular and respiratory systems. Dangerous potentiation of narcotics was not seen.

Irritation at the site of injection can occur. The drug is rapidly eliminated and postoperative depression is unusual However, if anaesthetic agents (particularly Pentothal or ether) are used in moderate amounts following Pacatal administration, postoperative depression may be prolonged for two to three hours

Further investigation of this agent is considered desirable.

\section{ACKNOWLEDGMENTS}

The authors are indebted to Warner-Chlcott Laboratories, Toronto, for the supply of Pacatal required for these studies.

We also wish to thank Dr Colin C. Ferguson for his encouragement and 
suggestions. The help of members of the Departments of Anaesthesia, partıcularly Dr. T. McCaughey, is acknowledged.

We wish to thank Dr. M. Saunders for his co-operation in arranging the E.K.G. and E E.G. studies and for his interpretation of the electro-encephalograms.

\section{RÉSUMÉ}

Tout en repassant l'histoire de l'introduction d'un nouveau dérivé phenothiazıne, on a fait allusion au concept de médicaments "atarax ques."

On a également revu rapıdement la pharmacologie de "Pacatal" chez les anımaux ansı que les résultats des travaux cliniques réalisés par d’autres chercheurs.

Ce traval se base sur des observations fattes avec "Pacatal" en chirurgie chez 352 patients, en obstétrique chez 44 patients et en d'autres circonstances chez 3 patients

Sans tenır compte du mode d'administratıon, des doses de 100 à $200 \mathrm{mgms}$ ( $1 \mathrm{mgm} / \mathrm{lb}$ ) ont été jugées efficaces

Parmi les effects favorables, on note: une bonne sédation pré-opératoire, un calme plus marqué que l'hypnose, un contrôle facile de l'induction anesthésique (entre anesthésie et analgésie), un besoin moindre d'agents anesthésiques, des effets antisécrétoires allant jusqu'à éviter l'emploı d'atropıne chez l'adulte, une ıéponse nơrmale aux vasopresseurs, une pérıde post-opératoire tranquille, des nausées et des vomissements post-opératorres dıminués

On a trouvé que le médicament ne produisait relativement pas de dépression sur les systèmes respiratorres et cardıo-vasculaires, il n'a pas produit non plus de potentralısation dangereuse des narcotiques

A l'endroit de l'injection, une irritatıon peut apparaître. Le médicament est rapidement éliminé et 1 l est rare d’observer une dépression postopératorre Cependant, s1 certains agents anesthésiques (particulièrement le pentothal ou l'éther) sont employés en quantté modérée après une administration de Pacatal, la dépression post-opératorre peut ètre prolongée de 2 à 3 heures

De plus amples recherches sur cet agent seraient désirables

\section{REFERENCES}

1. LABOHT, H \& HugueNaRd, $P$ L'hibernation artificielle par moyens pharmacodynamiques et physiques Presse méd, 13 octobre. 1951 C A S.J 591329 (1951)

2 Leading Article. Pharmacology of Chlorpromazine. Lancet, 1.337 (1955)

3 Fabing, H D A New Blocking Agent against the Developrent of Expermental LSD-25 Psychosis Paper read before the American Psychiatric Association, Galveston. Texas

4 Dobkin, Allen B, Wehling, Benjamin, Gross, Gilbert, \& Mendelsohn Harvey Chlorpromazine in Anaesthesia. Anaesthesia, 10.328 (1955).

5 Leading Article. Reser oine and the Nervous System Lancet, 21326 i 1955)

6 Conference, New Yor Academy of Sciences Reserpme in the Treatment of Neuropsychiatric, Neurological, and Related Clinıcal Problems Ann New York Acad. Sc. 61 1-280 (1955)

7 Bonrus, Joseph C. Study of Effect of Miltown (2-Methyl-2-N-F'ropyl-1, 3-Propanediol Dicarbamate) on Psychiatric States J A M A , 1571596 (1955)

8 Lemere, Frederick. New Tranquilizing Drugs Northwest Med. 541098 (1955) 
9 Davies, E Beresford. A New Drug to Relieve Anxiety. Brit Med. J 1480 (1956).

10 Condy, Anthony \& Jewesbury, Eric C,O. A Clinical Trial of Benactyzine Hydrochloride ("Suavitı") as a Physical Relaxant. Brit. Med J. 1485 (1956)

11 Nieschulz, O, Popendiker, K., \& SACK, K. H Pharmakologische Untersuchungen uber N-Allkyl-piperidyl-phenothiazinderivate, Acute Toxicity and Comprehensive Pharmacological Report on Pacatal Arzneimittelforschg 4232 (1954)

12 Nieschulz et al. See item 11

13. Gaderman, E. \& Donat, $K$ Zur Beemflussung der Irritabilitat des Herzens in der Narkose. Detailed Account of Irritability of the Heart in Experimental Dogs (with electrocardıgraphs) Kilın Wchnschı 32713 (1954).

14 Donat, K. Zur Verhuetung von Rhytmusstoerungen des Herzens bel operativen Eingriffen, Prevention of Arrythmias of the Heart during Operations Der Anaesthesist, 465 (1955)

15 Honatz, $\mathrm{K}$ Die Vorteıle der potenzıerten Narkose mit Abkuhlung, Special Emphasıs on Mechanical Devices for Undercooling durıng Anımal Experımentation and Human Surgery. Kaltetechnik S 28 (1954)

16 Gilbert, R G. B , Dobkin, Allan B \& Lamouneux, Louis. Investigation of New Drugs, with special reference to Largactl as an Example Can Anaesth Soc J, 25 (1955)

17 Horatz, K Die potenzierte Narkose ohne und mit Unterkuhlung, Potentiation of Narcosis with Pacatal Munchen med Wchnschr 96426 (1954)

18 - - Die potenzierte Narkose mit dem Phenothiazine-korper P 391 Potentiation of Narcosıs with a Phenothiazine Derivative P 391 Der Anesthesist, 3193 (1954)

19 - - Private communication to Promonta (1955)

20 Kueinsorge, H. \& Rosner, K. Zur Schlaftherapie, Therapeutic Sleep Neuralmedizin 25 (1954).

21 Werenberg, H Private communication to Promonta (1955)

22. JePSEN, N P Private communication to Promonta (1955)

23 Linau, H Private communication to Promonta (1955)

24. Lindsay, JoHN $\mathrm{H}$ Private communication

25 KLINE, N S \& JACOB, G M Use of Pacatal in Psychuatry Am J Psychiat, 112(1) 63 (1955).

26. Martin, Elizabeth M. A New Approach to the Control of Shock Can Anaesth Soc J $2 \cdot 222(1955)$

27 Melville, K I. Editorial Evaluation of New Drugs in Anaesthesia Can Anaesth Soc J, 2 I (1955)

28. Gilbert et al. See item 16.

29 Vandewater, S. L \& Gondon, R A Largactil in Anaesthesia Can Anaesth Soc J, $223(1955)$ 